\title{
Public Goods and Economic Development *
}

\author{
Timothy Besley, London School of Economics \\ Maitreesh Ghatak, London School of Economics
}

July 27, 2004

\section{Introduction}

Effective provision of public goods is a key determinant of quality of life. Conventional approaches to poverty measurement look only at private goods, but this view is too narrow. Access to safe drinking water, sanitation, transport, medical care, and schools is essential both as a direct component of well-being as well as an input into productive capability.

The rich have the option to seek private alternatives, lobby for better services, or if need be, move to different areas. The poor frequently do not.

*The authors are respectively Professor of Economics and Political Science, and Professor of Economics at the LSE. This paper has been prepared for Policies for Poverty Alleviation (ed.) Abhijit Banerjee, Roland Benabou, and Dilip Mookherjee. We thank Markus Goldstein, Dilip Mookherjee, and Inger Munk for helpful comments. 
This accentuates deprivation that is measured on a more conventional private consumption basis. Households that appear to enjoy very similar levels of private consumption may in reality enjoy have very different standards of living once public goods are taken into account. Mechanisms for effective delivery of public goods and services are therefore central to any credible poverty reduction strategy. This is increasingly recognized by development policymakers. For example, the UN's Human Development Index published since 1990 is an attempt to take a broader perspective by including indicators like life expectancy and literacy. The World Bank's World Development Report of 2004 was devoted to the topic of improving public service delivery to the poor.

There are two broad categories of public goods that are needed to strengthen the position of the poor in developing countries:

- Market supporting public goods - those state interventions that make it feasible for the poor to participate in markets and hence benefit from gains from trade.

- Market augmenting public goods - which deal with cases where even a well-functioning market will not provide the correct level of the public good.

In both cases, it is well known that uncoordinated private actions will lead to under-provision of public goods. The main issue is what institutional arrangements have a comparative advantage in dealing with this underprovision. 
The traditional view in economics was to equate public goods to government provision. The state was viewed as an actor that stands above the market and is able to correct failures without introducing any new distortions. Also, in this view, non-state non-market institutions such as voluntary and community organizations were either entirely ignored or were thought to be transitional phenomena in the development process whose functions would eventually be displaced by state or market activity.

We will argue that this view is now defunct. When it comes to public goods provision, traditional boundaries between the state and the private sector do not provide a very useful analytical basis. It is now widely appreciated that government failure may be as important as market failure, and the mere existence of the latter does not necessarily justify government intervention. To the extent government intervention is called for, this does not automatically mean direct involvement of the state in economic activity and could entail an indirect involvement through partnership with the private sector, and the "third sector" consisting of voluntary and community organizations.

Despite the overwhelming evidence that a large fraction of government expenditure in developing countries on the provision of public goods do not reach the beneficiaries, public policy debates often continue to revolve around "how much", i.e., how much money is spent by the government on some particular public good. ${ }^{1}$ Clearly, the question to ask is "how", i.e., designing

\footnotetext{
${ }^{1}$ For example, for some government schemes targeted for the rural poor in India the "leakage" of funds is as high as 70\% (Farrington and Saxena, 2004). Also, doctors, and nurses in government medical centres and teachers in public schools do not regularly show up to work. Banerjee, Deaton and Duflo (2004) report that on average $36-45 \%$ of medical
} 
effective mechanisms for the delivery of public goods. This is the main theme of this chapter. It is organized as follows. In the next section, we discuss different kinds of public goods that are vital to the poor and the evidence we have on their value. In section 3, we discuss spontaneous or voluntary private provision of public goods by the beneficiaries. In section 4 we discuss formal provision of public goods where the government or some other organization is in charge of providing the public good, with special emphasis on institution design issues. Section 4 concludes.

\section{Types of Public Goods}

\subsection{Market Supporting Public Goods}

The key market supporting public good is provision of law and order. The Weberian view of the state puts the monopoly of force as the sine qua non of state structures. This can be justified on public good grounds - competitive provision in the presence of externalities implies sub-optimal private provision. Indeed, where we see private provision, it is frequently through social networks for enforcing contracts. However, this leads to restriction of potential trade to only those within the network. From the point of view of the economy as a whole, this is sub-optimal. It would better to permit trade personnel are absent in the health care centres they studied rural Rajasthan. Since some of these centres are staffed by only one nurse, this high absenteeism means that these facilities are often closed which drives the poor to unregulated and mostly unqualified private providers. Kremer et al (2004) report an average absenteeism rate of $25 \%$ of teachers in government primary schools in India. 
with those outside the network.

Inadequate law and order is one of the principal symptoms of state failure throughout the developing world - the state is too weak in some dimensions and overbearing in others. It is too weak in failing to stand up to strong vested interests while failing to guarantee legal remedies to those with legitimate claims. It is overbearing when it exercises arbitrary authority and overrides judicial independence.

While "law and order" is often seen as a preoccupation only of businessmen and conservative politicians, the poor have much to gain from an efficient and transparent legal system, whether it is in he form of the ability to get a loan without huge collateral requirements, protection from unlawful eviction or seeking recourse from exploitative behavior of unscrupulous moneylenders and employers. ${ }^{2}$ The judicial system in developing countries often suffer from a shortage of resources which results in slow and/or ineffective resolution of disputes. ${ }^{3}$ On top of this, since access to the legal system is often governed by an individual's wealth or influence, the poor suffer disproportionately from failures of the legal system. There is strong evidence that improving property rights can enhance the possibilities for the poor to participate in markets. For example, Field (2003) examines a land titling

\footnotetext{
${ }^{2}$ Hernando De Soto (2000) has argued that the poor accumulate huge assets in their shanty homes and small businesses, but because they have no legal protections, they cannot access credit, nor can they safely invest. If the owner tries to obtain a title he will spend years doing it. Worse, he will risk having the property condemned and torn down.

${ }^{3}$ Djankov et al (2003) present evidence on the time it takes to collect a bounced check in various countries. For example, in the US it takes 54 days, in the UK 101 days, and in Pakistan, a year.
} 
program in Peru and shows that there is a significant gain in labor market participation by households who gain access to land titles.

Law and order is a far from being a homogeneous public good. Around the world we see two broadly competing systems of law - the civil law system and the common law system. These differ both in terms of the implementation of laws and the relationship between the political and legal systems. Glaeser and Shleifer (2002) have recently argued that there are important economic consequences for the choice of a legal system for economic prosperity. They argue that civil law systems are more vulnerable to abuse by bad governments, leading to insecure property rights and poor governance in general.

If the legal system is weak, then goods that would normally be considered private goods can effectively become public goods. For example, consider the extreme case where formal property rights cannot be enforced at all. Then what an individual produces in his or her farm is essentially a public good since other people can expropriate it. In this case, improving property rights and the legal system has extremely high payoffs in terms of improving investment incentives. ${ }^{4}$

There is also mounting macro-economic evidence that weak legal systems discourage investment and adversely affect economic development. For example, the score of average protection against expropriation risk compiled by Political Risk Services is significantly positively correlated with GDP per capita in a large cross section of countries. ${ }^{5}$

\footnotetext{
${ }^{4}$ Besley (1995) provides evidence on the positive effect of property rights on investment incentives.

${ }^{5}$ See for example, Acemoglu, Johnson, and Robinson (2001).
} 


\subsection{Market Augmenting Public Goods}

Market-augmenting public goods are much closer to the standard list from economics text books, such as health and education whose provision can bring benefits to society beyond the benefits to individuals. They also include some kinds of infrastructure investments such as in electricity, transport and telecommunications.

In general, economists have become much more circumspect about the case for state provision in all these cases. This is mirrored in practical experience. Infrastructural services, such as postal and telecommunication services, rail and air transportation have been privatized in many countries and in many others private providers coexist and compete with public agencies (Dixit, 2002). Public agencies routinely subcontract road construction and repair work to private agencies. Whether private solutions are viable will depend on the nature of the legal system and the possibility for effective regulation.

In all cases, it has become evident that only some parts of the sectors in question have substantial public good components. For example, electricity distribution may have important network externalities while electricity generation is not really a public good. Public health interventions such as clean water and vaccination have much stronger public good components than some kinds of curative treatments. In universities, research is a public good which generates externalities that travel far beyond the campus, but teaching is not a public good in this sense. This should lead to solutions for provision that reflect the degree to which private action fails to serve the social good. 


\section{Spontaneous Provision of Public Goods}

The canonical model of private provision of public goods is founded on the importance of free-rider problems in affecting individual incentives. The central proposition is that in the absence of coordination, cooperation or coercion, a group of independent individuals is unlikely to be able to provide public goods at the socially optimal level even if they care about the level of public goods provided. Their private incentives to voluntarily contribute towards provision will be inadequate since they will receive only a fraction of the total benefit but bear the full cost. If we allow for altruism, things are more promising. But the general prediction is that things will fall short of the first best as described by the Lindahl-Samuelson rule.

Recent research in economics has studied spontaneous collective action in response to this problem. It is important to understand when conditions favour collective action. The main insights from recent theoretical models in economics are that this is more likely when (i) interactions are more likely to be repeated since those who refuse can more easily be punished; (ii) when information is good so that individuals' actions to assist in public good provision can be observed and (iii) there is a strong social structure that can

be used to ostracize individuals or can be used to withdraw other forms of cooperation.

These conditions are most likely to be satisfied in traditional societies where social ties and communities are strong. It is an irony of the development process that it sows the seeds of destruction for the basis of collective action by voluntary means, necessitating the creation of more formal institutions to provide public goods. That said, there is now plenty of evidence 
that collective action based on social ties can remain strong for many forms of activities, even those in developed economies where trust is important.

Social networks are a key part of the fabric for the private provision of public goods. This is true for market supporting public goods. For example, McMillan and Woodruff (2002) discuss the provision of contract regulation in networks. However, since these are restricted to small groups which are socially connected, clearly they are very imperfect substitutes for formal legal enforcement. Networks are equally important for market augmenting public goods. For example, Wade (1988) describes the importance of social networks in the regulation of water distribution in India.

However, networks tend to lead to a patchy solution to public goods provision - those outside the network receive less access to public goods. Network provision could therefore be a source of inequality. Networks may also constitute a break on mobility as individuals are reluctant to lose the benefits of network membership. Nonetheless, inequality in access may also be a feature of formal provision - depending on the way in which the political process allocates public goods.

Recent research on spontaneous collective action is making the role of inequality in public good provision more apparent. The basic model of free riding may suggest that income or wealth inequality should favour public good provision if the rich are more likely to step in and provide the public good on behalf of the whole community. This is likely to be case if the marginal benefit from the public good is increasing in wealth - for example, a rich farmer has the most to gain from a well functioning irrigation canal.

However, there are reasons to doubt this "neo-feudal" vision of a patrician 
class on whom the poor are dependent. There are a number of good reasons to think that inequality can reduce incentives for spontaneous collective action. First, it may be that there are reasons to think that heterogeneity of any kind creates greater social distance that weakens the use of social ties. For example, Miguel and Gugerty (2002) find evidence that social sanctions, which are an important mechanism for sustaining collective action, work less effectively in ethnically diverse communities. Second, the assumption of decreasing returns, a standard one in most economic contexts, implies that the more scarce an input is in a given production unit, the higher is its marginal return. As a result, one would expect a more unequal distribution of this input across production units to reduce efficiency ${ }^{6}$

These theoretical possibilities are now borne out by empirical studies suggesting that inequality and population heterogeneity and are impediments to public goods provision. In a study of 48 irrigation communities in south India Bardhan (2000) finds that the degree of inequality in landholding among the irrigators has a significant negative effect on cooperation on water allocation and field channel maintenance. Similar results have been reported by Dayton-Johnson (2000) from his analysis of 54 farmer-managed surface irrigation systems in central Mexico.

\section{Formal Provision of Public Goods}

There are two main kinds of formal institutions for provision of public goods: governments and non-governmental organizations (NGOs). The latter are

\footnotetext{
${ }^{6}$ See Bardhan, Ghatak, and Karaivanov (2002) for a formal treatment of this trade-off.
} 
private organizations funded by private donors and governments which are typically run on a non-profit basis. Whether provision is public or private, incentive problems abound in formal provision of public goods. These are concerning how projects are selected and employees are motivated to provide goods with wider social benefits. These issues have received only limited attention in existing analyses. But recognizing this may go to the heart of what form of provision is optimal.

We discuss formal provision of public goods in two steps. One key set of issues concern the determinants of the level and composition of public goods provision. Next, we discuss how to organize provision, taking the funding level as given.

\subsection{Determinants of the Level and Composition of Pub- lic Goods Provision}

To study the financing and distribution of public goods one cannot ignore the

political system which governs how policy-makers are chosen, and what kind of policies are adopted. There is little doubt that the state has been and will remain a central player in public goods provision. As long as it monopolizes coercion, it has the only viable way of raising significant revenues needed to fund ambitious programs of public good provision. The earlier economics literature somewhat naively assumed the state to be some sort of a planner who was interested in maximizing social surplus. The new political economy literature has put back politics at the heart of policy choice.

Economists have recently become sanguine about the use of constitutional engineering in improving government. This is partly motivated by 
an improved understanding in the way in which incentives work under different rules. For example, Persson and Tabellini $(1999,2002)$ argue that proportional representation systems and parliamentary systems provide better incentives for provision of public goods. They also find evidence for this proposition in cross-country data.

Another interesting possibility that has been tried in India, is the use of political reservation. A certain proportion of seats are reserved for disadvantaged groups - such as low caste groups or women. This boosts their political power. This can make the political system more representative of their interests and hence the bundle of public goods provided by the state can be better targeted to their interests. There is mounting evidence (see Besley et al (2004), Chattopadhyay and Duflo (2002) and Pande (2003)) that this can change the priorities of government.

It is also becoming clear that there is a variety of complementary institutions are needed to support the state in delivering its functions effectively. Key among these is the media. If voters are uninformed about policy and politicians, they have little means of disciplining incumbents for poor performance. Agency problems on the part of politicians can be mitigated by effective media. Besley and Burgess (2002) argue that states in India with greater newspaper circulation also have governments who are responsive to shocks affecting the rural sector such as droughts and floods.

A number of recent empirical studies suggest complex interactions over time between the economic environment and political institutions that affect a country's current economic condition as well as the level and composition of public goods provision. 
For example, Iyer (2003) argues that there is a persistent effect on public goods provision from patterns of colonial settlement in India. She finds that areas that were annexed by the British during the colonial period have lower levels of public goods like schools, health centres and roads in the postindependence period compared to areas that were ruled by native kings.

Countries in the Caribbean islands or Spanish America such as Argentina, Brazil, and Cuba were much richer than the US or Canada until at least the beginning of the 19th century. Their fortunes were based on a plantation economy that employed slaves imported from Africa or the native population. This implied that the initial distribution of human and physical capital were very unequal. The elites in these countries, mostly of European descent, enjoyed a political hegemony and chose institutions (such as rules about land ownership) to perpetuate their power. In contrast, the Northern United States and Canada had neither a climate favorable to plantation economy nor a substantial endowment of native or slave labour. Thus the population consisted largely of people of European descent with similar levels of human and physical capital. Most operated as independent proprietors. Engerman and Sokoloff (2000) argue that this affected their relative progress towards democracy and in turn affected public policy especially, the development of public primary schools where the US and Canada performed exceptionally well compared to the Caribbean islands or Spanish America.

A parallel set of studies shows that ethnically diverse societies tend to provide fewer public services. According to calculations by Easterly (2001) most ethnically diverse societies have half the schooling, one-thirteenth of the telephones per worker, nearly twice the electric power losses, and less 
than half the share of roads that are paved compared to most ethnically homogeneous societies. What could be the mechanisms that lead to this? If externalities are limited to within ethnic groups, then the total demand for public goods that benefits all groups such as roads and education will be less. For example, if ethnic groups are separated geographically, there will be little demand for interregional travel. Similarly, if the different ethnic groups speak different languages and have different cultures, they will be less willing to support investment in public education.

\subsection{Institution Design Issues}

We now discuss aspects of institutions design that are critical in understanding public goods provision. Thus, we abstract from funding issues and ask how public goods can be provided effectively for a given funding level. We focus on four issues: how incentives work in organizations charged with providing public goods, the scope for private provision via NGOs and contracting out to for-profit firms, the case for decentralized provision, and the role of competition.

\subsubsection{Incentive Design for Public Goods Provision}

Whether provided in state or private organizations, individuals need to be motivated to provide goods that achieve collective benefits. The traditional model of state provision assumes away incentive problems, assuming that the government can stipulate and enforce a level of provision. It implicitly assumes that individuals who work in the public sector need little direct motivation to pursue the social good. Rewards therefore depended little 
on performance. The implicit assumption was that teachers, health care professionals and bureaucrats are publicly spirited and that this was enough (see LeGrand, 2003).

Under the billing of the "New Public Management", there is now much more attention paid to incentives in the public sector. The two central propositions are: (i) that beneficiaries need to be given more say in the provision of public goods and services and (ii) incentives for public servants needed to be more high powered - explicitly linking outputs and inputs. At some level, this is compelling. After all, it seems to mirror the model that prevails in the private sector. Beneficiaries or consumers have the right to choose among different providers, and workers and managers receive bonuses for generating higher profits.

But before embracing this new paradigm, it is important to remember where it came from. It was born out of efforts, most notably in the U.K. under Margaret Thatcher, to decrease the size of the public finances going to public goods and services while preserving service levels. The prevailing view was that the public sector was getting rents which could be extracted and converted to better service levels.

There are some important differences between public and private goods which imply that incentive issues are somewhat different and a mechanical application of what is efficient in the private sector is likely to be misleading. Also, it is important to note that this has nothing to do with who owns or operates the organization that provides the public good, public, private for-profit, or non-profit. These issues are fundamental to the technology of public goods production and consumption. 
First, in many cases the goods are complex and as a result the objectives of the relevant organizations are somewhat imprecise. For example, the objective of a school is to provide "good education", but this is much harder to define compared to say, production of rice or provision of banking services or even some public services such as garbage removal or power supply. This means that in these cases it would be hard to find good performance measures.

Second, the reason why such goods are complex is because they involve several dimensions. For example, good education involves students being able to achieve high scores in standardized tests, but also encouraging a spirit of creativity, curiosity and inculcation of good values. The former is easy to measure but if teachers are rewarded just on the basis of the performance of students in tests, this might lead to an excessive focus on test-taking skills at the expense of the other components of a good education. This makes provision of incentives hard when employees have to perform multiple tasks (Holmstrom and Milgrom, 1991). Similarly, if hospitals are given incentives to cut costs, they are going to sacrifice quality by refusing to treat certain types of illnesses or being excessively selective in using expensive medical procedures.

Third, individuals who choose to work in an organization that supplies public goods may be motivated not just by money, but also by the "cause". There are a number of different explanations for this. Individuals could be altruistic caring about the benefits that they achieve for others. This could also be ideological, with individuals believing that their private actions fulfil some wider objective (religious or political). Outside of economics, this 
is given the general label of "public service motivation" (Francois (2000)). Behavioral economists have urged going beyond the narrow conception of a self-interested economic agent, and emphasized the importance of the motive to reciprocate and the desire for social approval (Fehr and Falk, 2002). The role of incentives is to harness these feelings and to put them to the social good in an efficient manner.

Fourth, there may be many competing views on the right way to provide public goods - not just on the optimal level of provision, but crucial aspects of project design. For example, should a school run by a non-profit be allowed to teach religious material or just science and mathematics? This affects the extent to which agents working together to produce public goods and the beneficiaries have congruent objectives.

What do these considerations imply about how agents providing public goods should be rewarded?

In terms of standard incentive theory, it is well-known (see, for example, Dixit, 2002) that in these environments, low powered incentives are likely to be optimal. If performance measures are noisy, then making rewards very sensitive to performance does not give effective incentives, and imposes unnecessary risk on the employee. If the employee has to do several tasks, and some of these have good performance measures and not others, then making her pay sensitive to the good performance measures will cause her to substitute effort away from the other tasks, and could result in a loss of efficiency.

The fact that providers may be motivated is also very important. This may reinforce the tendency towards low powered incentives. If the employee 
receives a non-monetary reward from doing her job well, then clearly she can be paid both a lower wage and her pay does not have to be made very sensitive to her performance. Of course, the incentive structures offered for providing public goods may affect who chooses to work within the public goods producing sector. Lower wages may act as a screening device: attracting only those workers who have a desire to achieve the social good.

However, there are important caveats to this strategy. First, there may be a trade-off if individuals differ also in their abilities. With lower wages and low-powered incentives, the public sector may end up being a haven for well-meaning but incompetent individuals. There may also be an adverse selection problem if there are some dishonest individuals who will use the public sector to pursue private ends. Besley and McLaren (1993) refer to the strategy of paying ultra-low wages since these agents are expected to take bribes as "capitulation wages". Under this strategy the public sector may end up being a haven for dishonest individuals.

The general point here is that a system of organization and remuneration for the provision for public goods will have to take into account not only how on-the-job incentives affect how those in the sector work, but also who is attracted to work there. In this context, it is important to note that, even if individuals are value-driven, whether they choose to exert extra effort might depend on whether the organization is run for profit (Francois, 2000). In similar vein, Besley and Ghatak (2003a,b) suggest an approach to public good provision which emphasizes the importance of mission formation in galvanizing effective organizations. Such missions serve to match individuals to organizations on the basis of their mission preferences. This also economizes 
on the need for formal incentives.

\subsubsection{Public-Sector Provision versus Contracting out to Private For-Profits and NGOs}

In the developing world, NGOs have been increasingly involved in the provision of relief and welfare, social services, and various development projects (e.g., agricultural extension, micro lending) directly or in partnership with the government. ${ }^{7}$ This raises questions about alternative organizational forms of public goods provision.

That the government should bear some responsibility of financing public goods provision is quite uncontroversial. However, as to whether is should directly provide it through the public sector is the subject of active policy debate, in developed as well as developing countries. Organizational alternatives include contracting out to private for-profit firms or non-profit firms (which are typically referred to as non-governmental organizations or NGOs in the developing world), and public-private partnerships.

The advantage of government or NGO provision stems from the fact that no one is a residual claimant. This dulls incentives for the manager of such an organization to minimize waste. In contrast, if provision is through a for-profit firm (which is subsidized by the government because the good in question is a public good), the manager or the owners have strong incentives to run the operation in as cost-effective a manner as possible. The trouble

\footnotetext{
${ }^{7}$ According to the UNDP (1993), there are more than 50,000 NGOs working at the grass-roots level in developing countries whose activities have affected the lives of 250 million individuals.
} 
is, sometimes this can be at the expense of quality, especially when it is hard to contract on. For example, a school run by a for-profit firm may be cost-efficient, but it may be unwilling to admit students from disadvantaged backgrounds or take extra care of students with learning disabilities. To the extent these things can be contracted on, the government may try to create incentives for these schools to admit such students. But if that is not the case, the choice of organizational form of delivery would depend on whether cost-cutting or quality-maintenance is more important. ${ }^{8}$

A key issue in the choice between government provision and provision through NGOs are non-contractible aspects of project-design. As we discussed in the previous subsection, people who may have the same valuation of a public good (e.g., dedicated teachers) may have very different views on the right way to provide it (e.g., importance of religion in the curriculum). NGOs may attract more motivated workers by providing a better match between the mission of the organization, its workers and the beneficiaries. To the extent government policy is driven by electoral concerns, this may result in some public servants having to carry out policies which they do not necessarily believe in, which will undermine motivation. However, the flip-side of this is, contracting out to NGOs may involve project-design that does not reflect the preferences of the median voter or may lead to a polarized society along religious or ethnic lines. To the extent these elements cannot be regulated, the government may decide to provide public goods in-house even when contracting it to a NGO would have saved costs or ensured greater motivation on the part of employees.

\footnotetext{
${ }^{8}$ See Hart, Shleifer and Vishny (1997).
} 
Another key issue in the government versus NGO choice is that of accountability of NGOs. The prevailing view of public goods provision by NGOs has transferred the traditional model of the public sector as staffed by highly motivated staff to the private sector. Just as public sector workers were thought to be "beyond incentives" so now it is the NGO worker. However, one has to be careful about the possibility of opportunistic behavior by NGOs. In countries with high unemployment and bad job prospects in the private sector, NGOs often become an instrument for rent-seeking activity at the expense of donors. The weak accountability structures of NGOs become worryingly apparent in this context. Unless there are many NGOs operating in the area, the beneficiaries are not in a position to vote with their feet. The same is true of government provision. But NGOs do not have to worry about getting elected. This can be a good thing in some respects, but it also means they are not accountable to their beneficiaries. ${ }^{9}$

A related but distinct question is, even when the government decides to collaborate with NGOs, what form should that collaboration take? Should the government retain the ownership of the public good (say, a school) and ask a NGO to run it or should it finance or subsidize a school that is owned by NGOs?

\footnotetext{
${ }^{9}$ It seems that the time is ripe to insist on greater transparency in NGOs which would include a much greater use of evaluation studies of their actions. While this is beginning and NGOs have sometimes been on the frontier in promoting evaluation of interventions, there are cases that are shrouded in mystery with myth triumphing over measurement. A glaring example of this is micro-credit provision by NGOs which is crying out for randomized evaluation.
} 
The property rights approach, pioneered by Grossman, Hart and Moore (see Hart, 1995), studies this questions in the context of private goods where the allocation of ownership affects incentives to undertake non-contractible relationship-specific investments. Because these investments are not contractible, there is ex post bargaining over the surplus that is generated by these investments. Ownership positively affects bargaining power as the owner can always threaten to fire the other party after investments have been sunk. Therefore, the owner can extract a higher share of the surplus of the project, and this improves his investment incentives. However, by the same token, it reduces the investment incentives of the other party. Therefore, according to this theory the party whose investment is more important for the project should be the owner. In particular, if one party has no useful investment to make, he should never be the owner since that will only undermine the incentives of other parties.

Besley and Ghatak (2001) develop a theory of ownership in public goods provision. They show that how much a party values a project is critical for who should own the project, irrespective of whose investment is more important. In particular, even if a party has no useful investment to make, he could optimally be the owner if he values the public good the most. This result reflects a key property of public goods - even if a party is fired after investments are sunk, he continues to care about the outcome of that project. This is never the case with private goods. Due to this property it is efficient to give the highest valuation party ownership of the project, as it gives the best investment incentives to that party, as well as to others. This reinforces the message that, when public goods are being considered, the motivation of 
providers matters.

\subsubsection{Decentralization}

One of the key issues is the extent to which the responsibility of public good provision should reside with local or central government. Clearly where public goods have national repercussions, as with defence, then local solutions are likely to have spillovers across jurisdiction boundaries and this would make local provision inefficient.

There are two main arguments for decentralization in public goods provision. The first is based on the importance of exit options as citizens "vote with their feet". Long ago, Tiebout described a "quasi-market" mechanism for public good provision that worked on this basis. However, it is arguably of limited relevance in the context of developing countries where mobility costs are high due to pure infrastructure and segmented markets.

Arguments for decentralization have, therefore, for the most part hinged on improved accountability either due to improved information being brought into the political process or a better reflection of local preferences in the supply of public goods.

There is emerging evidence that decentralization does have an impact on local government performance. For example, Foster and Rosenzweig (2001) analyze Indian states which vary in terms of how decentralized they are and find that more decentralized states produce a mix of public goods that reflect more closely the interests of the local population.

However, some areas may lack the preconditions for effective accountability due to the power of entrenched elites and poor political competition. 
If economic and political power is concentrated in the hands of the local elite, then there is a danger of elite capture in decentralized governments. ${ }^{10}$ The local elites may not only be indifferent to the general promotion of local public services but even to obstruct it to prevent the empowerment of disadvantaged groups. ${ }^{11}$

\subsubsection{The role of competition}

Another key organization design issue concerns the role of competition. The well known effect of competition in the context of private goods is that in order to retain existing consumers or attract new ones, an organization has to either cut costs or improve quality. To the extent cutting costs or increasing quality is at the expense of monopoly rents, consumers are better off, even though owners and employees of the organization can be worse off because they lose "a quiet life", to borrow Hicks' phrase. Cutting costs can be at the expense of quality. Competition works best when consumers are well-informed. If this is not the case poor quality organizations can survive for long periods even with competition. To the extent being informed is correlated with being educated or affluent, this may lead to both inefficient and inequitable outcomes. This calls for appropriate regulatory institutions, and legal protection.

Can these arguments in favour of competition for the provision of private goods borrowed in the context of public goods? According to some advocates of school competition and vouchers, such as Hoxby (2001), the answer is yes.

\footnotetext{
${ }^{10}$ See Bardhan and Mookherjee (2000).

${ }^{11}$ See Dreze and Sen,1999
} 
Competition from private organizations can induce public organizations to get their act together to hold on to funding and to their clientele - competition is a "rising tide that raises all boats". ${ }^{12}$ Hoxby draws the parallel between this and the effect of entry of Federal Express and DHL into the package-delivery market in the US, which forced the US Postal Service to improve quality, cut costs and offer new products such as Express Mail. Opponents argue that competition will lead to cream-skimming. New schools will attract students from higher income and education groups. As these students leave, taking with them the per-capita government funding, poorer students in old schools will be strictly worse off. However, this is not an argument against competition per se. It merely calls for "smart" vouchers whose value depend on the socio-economic background of the student, so as to make them attractive to new schools.

Also, competition in the context of public goods can take interesting forms. For example, Besley and Ghatak (2003a, b) argue that schools can be viewed as competing by picking different kinds of curriculum and attracting teachers who are most motivated to teach according to that curriculum. One element of the curriculum could, for example, be whether religious instruction is included. Well matched schools can forego incentive pay and rely exclusively on agents' motivation. This explains why some schools (such as Catholic schools) can be more productive by attracting teachers whose mission-preferences are closely aligned with those of the school management. More generally, a decentralized schooling system where missions are developed at the school level will tend to be more productive (as measured in

\footnotetext{
${ }^{12}$ See Hoxby (2001).
} 
our model by equilibrium effort) than a centralized one in which a uniform curriculum (mission) is imposed on schools by government.

\section{Conclusion}

We have argued in this essay that the standard public-private dichotomy is of limited use in thinking about institution-design for public goods provision. The following news that hit the headlines recently highlights this starkly. ${ }^{13}$ On July 16, 2004 an illegal thatched roof of a popular private school caught fire in a small town called Kumbakonam in the southern Indian state of Tamil Nadu. Around ninety young children between the ages of 6 and 11 died. This was a private school but was subsidized by the government. Its popularity, especially among working class parents, came from the fact that local government schools were of poor quality. As part of receiving government aid, the school was supposed to be inspected every three years to see if it met government fire, health and safety standards. Those inspections were never carried out.

This ghastly tragedy dramatically highlights the need to come out of the private-versus-public or government-versus-market dichotomy in thinking about public goods provision. First, this was a hybrid school: privately owned and run, but receiving government funds. Second, the event underscores the fact that private (or hybrid) schools too need to be regulated - being private is no guarantee of quality. However, this does not mean that we should get rid of private schools and supply education only through government

\footnotetext{
${ }^{13}$ See Rohde (2004).
} 
schools. There were government schools in this town which the parents of children attending this school could have sent their children to, but chose not to because of poor quality. Also, similar incidents are reported regarding government schools regularly in the media. Finally, a big part of the fault lies with government regulators. If they were doing their jobs, this tragedy could be avoided.

How an organization performs depends on its internal design, the competitive environment it faces, the regulatory environment in that sector, and the overall institutional environment of the economy (flow of information, efficiency of dispute resolution and contract enforcement etc.). These elements are all important. If the regulatory environment is slack then competition is no guarantor of success. However, the case for government monopoly is often weak too.

If a strict regulatory regime enforcing quality and safety standards is present then it is fairly uncontroversial to say that greater choice and greater competition is good. However, the ground reality of developing countries is that regulatory bodies do not do what they are supposed to do, and do everything that they are not supposed to do (e.g., demand bribes, harass firms as well as workers, consumers). However, even in this environment competition in other forms can act as a discipline device. A competitive media will expose regulatory lapses. A competitive polity will punish underperforming administrations. Competition and choice are ideas that are far too important to be left to champions of unregulated markets. They can and should be used to empower the poor. 


\section{References}

[1] Acemoglu, Daron, Simon Johnson, and James A. Robinson (2001), "The Colonial Origins of Comparative Development: An Empirical Investigation", American Economic Review, 91(5), 1369-1401.

[2] Banerjee, A., A. Deaton, and E. Duflo (2004): "Wealth, health, and health services in rural Rajasthan," American Economic Review (Papers and Proceedings), forthcoming.

[3] Bardhan, Pranab, (2000), "Irrigation and Cooperation: An Empirical Analysis of 48 Irrigation Communities in South India", Economic Development and Cultural Change, 48(4), 847-65

[4] Bardhan, P., M. Ghatak, and A. Karaivanov (2002): "Inequality, Market Imperfections, and the Voluntary Provision of Collective Goods", Working Paper, London School of Economics.

[5] Bardhan, Pranab, and Dilip Mookherjee, (2000), "Capture and Governance at Local and National Levles," American Economic Review, 90 (2), 135-39.

[6] Bardhan, Pranab, and Christopher Udry, (1999), Development Microeconomics, Oxford: Oxford University Press.

[7] Basu, Kaushik, (1997), Analytical Development Economics, Cambridge MA: MIT Press. 
[8] Besley, Timothy, (1995), "Property Rights and Investment Incentives: Theory and Evidence from Ghana," Journal of Political Economy, 103(5), 903-937.

[9] Besley, Timothy, Rohini Pande, Lupin Rahman and Vijayendra Rao, (2004), "The Politics of Public Good Provision: Evidence from Indian Local Governments," Journal of the European Economics Association, $2(2-3), 416-426$.

[10] Besley, Timothy and Robin Burgess, (2002), "The Political Economy of Government Responsiveness: Theory and Evidence," Quarterly Journal of Economics, 117(4), 1415-1451.

[11] Besley, Timothy and Maitreesh Ghatak (2001): "Government Versus Private Ownership of Public Goods", Quarterly Journal of Economics, $116(4), 1343-72$

[12] Besley, Timothy and Maitreesh Ghatak, (2003a), "Incentives, Choice and Accountability in Public Service Provision," Oxford Review of Economic Policy, 19(2), 235-49

[13] Besley, Timothy and Maitreesh Ghatak, (2003b), "Competition and Incentives with Motivated Agents", Working Paper, LSE.

[14] Besley, Timothy and John McLaren, (1993), "Taxes and Bribery: The Role of Wage Incentives," Economic Journal, 103(1), 119-141.

[15] Chattopadhyay, Raghabendra and Esther Duflo, [2001], "Women as Policy Makers: Evidence from an India-Wide Randomized Policy Experiment," typescript, MIT. 
[16] Dayton-Johnson, J. (2000), "The Determinants of Collective Action on the Local Commons: A Model with Evidence from Mexico", Journal of Development Economics, 62(1), 181-208.

[17] De Soto, Hernando (2000): The Mystery of Capital: Why Capitalism Triumphs in the West and Fails Everywhere Else, New York: Basic Books.

[18] Dixit, Avinash (2002): "Incentives and Organizations in the Public Sector: An Interpretive Review", Journal of Human Resources, 37(4), 696727.

[19] Djankov, Simeon, Rafael La Porta, Florencio Lopez-de-Silanes and Andrei Shleifer (2003): "Courts: the Lex Mundi Project", Quarterly Journal of Economics, 118(2), 453-517.

[20] Dreze, Jean and Amartya Sen (1999): India: Economic Development and Social Opportunity, Oxford University Press.

[21] Easterly, William, (2001): The Elusive Quest for Growth - Economists' Adventures and Misadventures in the Tropics, The MIT Press

[22] Farrington, J. and N.C. Saxena (2004): "Protecting and promoting livelihoods in rural India: what role for pensions?", Opinion, February 2004, Overseas Development Institute.

[23] Fehr, Ernst and Armin Falk (2002): "Psychological Foundations of Incentives", European Economic Review, 24 (2-3), 687-724. 
[24] Field, Erica (2003): "Entitled to Work: Urban Property Rights and Labor Supply in Peru", Working Paper, Harvard University.

[25] Foster, Andrew and Mark Rosenzweig, (2001): "Democratization, Decentralization, and the Distribution of Local Public Goods in a Poor Rural Economy", Working Paper, Brown University and University of Pennsylvania.

[26] Francois, Patrick, (2000): "Public Service Motivation as an Argument for Government Provision" Journal of Public Economics, 78, 275-299.

[27] Glaeser, Edward and Andrei Shleifer (2001): "Not-for-Profit Entrepreneurs", Journal of Public Economics, 81(1): 99-115.

[28] Glaeser, Edward and Andrei Shleifer (2002): "Legal Origins", Quarterly Journal of Economics, 117(4), 1193-1230.

[29] Grossman, Sanford and Oliver Hart, (1986): "The Costs and Benefits of Ownership: A Theory of Vertical and Lateral Integration", Journal of Political Economy, 94(4), 691-719.

[30] Hart, Oliver, (1995): Firms, Contracts and Financial Structure, Oxford: Oxford University Press.

[31] Hart, Oliver, Andrei Shleifer, and Robert Vishny (1997): "The Proper Scope of Government : Theory and an Application to Prisons", Quarterly Journal of Economics, 112 (4), 1119-1158. 
[32] Holmstrom, Bengt, and Paul Milgrom (1991): Multi-task PrincipalAgent Analysis: Incentive Contracts, Asset Ownership, and Job Design" Journal of Law, Economics and Organization, 7 (Special Issue), 24-52.

[33] Hoxby, C.M. (2001). "Rising Tide", Education Next, Winter.

[34] Iyer, Lakshmi, (2003), "The Long-term Impact of Colonial Rule:Evidence from India." typescript, MIT.

[35] Kremer, M., K. Muralidharan, N. Chaudhury, J. Hammer, and H. Rogers (2004): "Teacher Absence in India", Working Paper, The World Bank and Harvard University.

[36] LeGrand, Julian, (2003), From Knight to Knave, From Pawn to Queen, Oxford: Oxford University Press.

[37] McMillan, John and Christopher Woodruff, (2002), "The Central Role of Entrepreneurs in Transition Economies," Journal of Economic Perspectives, Summer, 16(3), 153-170.

[38] Miguel, Edward. and Mary Kay Gugerty, (2002): "Ethnic Diversity, Social Sanctions, and Public Goods in Kenya", Working Paper, Department of Economics, University of California, Berkeley.

[39] Persson, Torsten and Guido Tabellini, (1999), "The Size and Scope of Government: Comparative Politics with Rational Politicians," European Economic Review, 43(1), 699-735.

[40] Persson, Torsten and Guido Tabellini, (2002): The Economic Effect of Constitutions: What do the Data Say? MIT Press, 2003. 
[41] Pande, Rohini, [(2003), "Minority Representation and Policy Choices: The significance of Legislator Identity," American Economic Review, 93(4), 1132-51.

[42] Ray, Debraj, (1998), Development Economics, Princeton: Princeton University Press.

[43] Rohde, D. (2004): "In Fire, Striving Town Finds Dangers on Path to Modernization", The New York Times, July 18.

[44] Wade, Robert, (1988), Village Republics: Economic Conditions for Collective Action in South India, Cambridge: Cambridge University Press. 